\title{
Novel Ni-Co-Mo-K Catalysts Supported on Multiwalled Carbon Nanotubes for Higher Alcohols Synthesis
}

\author{
Venkateswara Rao Surisetty, ${ }^{1}$ Janusz Kozinski, ${ }^{1}$ and Ajay Kumar Dalai ${ }^{2}$ \\ ${ }^{1}$ Faculty of Science \& Engineering, York University, 4700 Keele Street, Toronto, ON, Canada M3J 1P3 \\ ${ }^{2}$ Catalysis and Chemical Reaction Engineering Laboratories, Department of Chemical Engineering, University of Saskatchewan, \\ Saskatoon, SK, Canada S7N 5A9
}

Correspondence should be addressed to Venkateswara Rao Surisetty; vrsurisetty@gmail.com

Received 25 December 2012; Revised 19 February 2013; Accepted 19 February 2013

Academic Editor: Valeria La Parola

Copyright (C) 2013 Venkateswara Rao Surisetty et al. This is an open access article distributed under the Creative Commons Attribution License, which permits unrestricted use, distribution, and reproduction in any medium, provided the original work is properly cited.

Alkali-promoted Ni-Co-Mo catalysts supported on multiwalled carbon nanotubes (MWCNTs) were prepared using 9 wt\% K, $4.5 \mathrm{wt} \% \mathrm{Co}$, and $15 \mathrm{wt} \% \mathrm{Mo}$, whereas $\mathrm{Ni}$ content was varied from 0 to $6 \mathrm{wt} \%$. The catalysts were extensively characterized and studied for higher alcohols synthesis from synthesis gas. Alkali-promoted trimetallic catalyst with 3 wt $\%$ Ni showed the highest total alcohols yield of $0.284 \mathrm{gm} /\left(\mathrm{gm}\right.$ of cat./h), ethanol selectivity of $20 \%$, and higher alcohols selectivity of $32 \%$ at $330^{\circ} \mathrm{C}$ and $9.0 \mathrm{MPa}$ using gas hourly space velocity (GHSV) of $3.8 \mathrm{~m}^{3}$ (STP)/ $\mathrm{kg}$ of catalyst/h and $\mathrm{H}_{2}$ to CO molar ratio of 1.25.

\section{Introduction}

Ethanol has been used as an additive for reformulated gasoline as unleaded gasoline has become the standard, and short ether compounds (MTBE, ETBE, etc.) have been banned as gasoline octane continues to improve in North America [1]. The catalytic conversion of syngas to ethanol, and other higher alcohols, is generally recognized as an interesting route for the production of clean fuels and petrochemical feedstocks from coal, natural gas, and hydrocarbon wastes via gasification [2]. The catalysts for higher alcohol synthesis (HAS) are divided into two main groups based on the product distribution [3]. Alkali-doped high-temperature $\mathrm{ZnCrO}$-based and low-temperature $\mathrm{Cu}$-based catalysts produce mainly methanol and higher branched alcohols $[4,5]$. Methanol synthesis catalysts modified with Fischer-Tropsch (FT) elements and modified Mo-catalysts are the second group of HAS catalysts. These catalysts yield a series of linear primary alcohols and gaseous hydrocarbons both with Anderson-Schulz-Flory (ASF) carbon number distribution $[6,7]$. Comparatively, molybdenum-sulfide-based catalysts showed a high proportion of higher alcohols at lower pressure and high temperature. $\mathrm{MoS}_{2}$-based catalysts can tolerate sulfur and coke-buildup as a result of higher alcohols synthesis.
When $\mathrm{MoS}_{2}$ is promoted with $\mathrm{K}_{2} \mathrm{CO}_{3}$, the same performance of the catalysts is achieved at a significantly lower temperature [8].

The alkali-promoted $\mathrm{MoS}_{2}$ catalysts promoted with Co showed high activity to alcohols and can also produce alcohols with a variable ratio of methanol to higher alcohols by changing the operating conditions $[9,10]$. The $\mathrm{CO}$ hydrogenation was studied over $\mathrm{K} / \mathrm{Co} / \mathrm{Mo} / \mathrm{Al}_{2} \mathrm{O}_{3}$ and $\mathrm{K} / \mathrm{Co} / \mathrm{Mo} / \mathrm{SiO}_{2}$ catalysts and found that all three elements are necessary for higher activity. Hydrocarbons and alcohols were produced in approximately equal amounts over both the catalysts [11]. Copromotion on alkali-modified $\mathrm{MoS}_{2}$ catalysts leads to the shrinking of $\mathrm{MoS}_{2}$ species, while Co exists mainly in the form of Co-Mo-S phase at low Co loading and partly in a $\mathrm{Co}_{9} \mathrm{~S}_{8}$-like structure at high Co loading [12]. This structural modification leads to the enhanced $\mathrm{C}_{1} \rightarrow \mathrm{C}_{2}$ homologation step that improves the formation of ethanol as the dominant product [13].

$\mathrm{Ni}$ is known as Fischer-Tropsch element which has strong methanation tendency in $\mathrm{CO}$ hydrogenation reaction. The effect of $\mathrm{Ni}$ for the production of higher alcohols was studied using La-promoted $\mathrm{Ni} / \mathrm{K}_{2} \mathrm{CO}_{3} / \mathrm{MoS}_{2}$ catalysts [14]. The authors found that $\mathrm{Ni}$ enhanced not only the $\mathrm{CO}$ hydrogenation activity but also $\mathrm{C}_{2+} \mathrm{OH}$ selectivity. This 
enhancement effect might be related to the improvement structure morphology of $\mathrm{Ni}$ and unique surficial chemical environment of the alkali-promoted $\mathrm{MoS}_{2}$ catalyst. Moreover Hedrick et al. [15] concluded that nickel was unique in keeping high activity after sulfur treatment on the Group VIII metals, which is advantageous for the $\mathrm{H}_{2} \mathrm{~S}$-contained feed gas. Chung and Pien [16] concluded that nickel showed an excellent ability for $\mathrm{CO}$ insertion, which has an important significance for higher alcohol synthesis. The formation of $\mathrm{Ni}$ Mo-S phase is related to the electron donation from $\mathrm{Ni}$ to Mo, decreasing the Mo-S bond strength to an optimum range, and thus significantly increasing the activity of the catalyst [17].

In our previous research, we have studied the effects of different loadings of active metals (Mo), alkali $(\mathrm{K})$ promoters, and metal promoters (Co and $\mathrm{Rh}$ ) on higher alcohols synthesis from synthesis gas using K-promoted monometallic, bimetallic, and trimetallic $\mathrm{MoS}_{2}$ catalysts $[8,13,18,19]$. The formation of hydrocarbons and methanol was significantly less over the K-promoted trimetallic catalyst compared to that of monometallic and bimetallic catalysts. It is important to prepare K-promoted trimetallic catalysts using inexpensive metals such as $\mathrm{Ni}$, as explained in the literature, to replace $\mathrm{Rh}$ for higher alcohols synthesis from synthesis gas.

A multiwalled carbon nanotube (MWCNT) is a new form of carbon material which is drawing special attention as a catalyst support [18]. MWCNTs provide a relatively inert support and high-temperature stability, which is similar to that of activated carbon (AC) support [20]. MWCNTs exhibit well-defined hollow interiors and display exceptionally high mechanical strength, thermal stability, and electrical conductivity [21]. Their unique characteristics, such as appropriate pore-size distribution, and nanosized channels, make them a promising support in $\mathrm{CO}$ hydrogenation reactions [22]. In our previous research, we have compared higher alcohols synthesis from synthesis gas using alkali-promoted trimetallic Co-Rh-Mo-sulfided catalysts that are supported on AC and MWCNTs [19]. It was found that total alcohols space time yield (STY) and selectivity were higher on the MWCNTssupported catalyst compared to catalysts supported on activated carbon. These results proved that support pore-size influenced particle size distribution, dispersion, and extent of reduction and plays an important role in diffusing the reactant molecules to the catalytically active centers that are located inside the pores [23]. The microporous structure of activated carbon-supported catalysts caused pore plugging due to the formation of coke and deactivation of the catalyst, which results in transport limitation in the reaction [24].

In the present paper, a series of MWCNTs-supported Nipromoted catalysts with $9 \mathrm{wt} \% \mathrm{~K}, 4.5 \mathrm{wt} \% \mathrm{Co}$, and $15 \mathrm{wt} \% \mathrm{Mo}$ are prepared by varying $\mathrm{Ni}$ content from 0 to $6 \mathrm{wt} \%$, and the catalytic performance for higher alcohols synthesis over these catalysts is investigated at optimum operating conditions.

\section{Experimental Method}

2.1. Preparation of Catalysts. Commercially available MWCNTs are used as catalyst supports and the catalysts were prepared by conventional incipient wetness method, as described in our preceding papers $[8,13,18,19,23-26]$.
Ammonium heptamolybdate tetrahydrate (AHM), potassium carbonate, cobalt acetate tetrahydrate, and nickel nitrate hexahydrate are used as precursors for $\mathrm{Mo}, \mathrm{K}, \mathrm{Co}$, and $\mathrm{Ni}$, respectively. At the first step, the support was impregnated with an aqueous solution of $\mathrm{K}_{2} \mathrm{CO}_{3}$, followed by drying at $120^{\circ} \mathrm{C}$ for $2 \mathrm{~h}$, and stabilizing in an argon flow of $50 \mathrm{~mL} / \mathrm{min}$ at $300^{\circ} \mathrm{C}$, at a heating rate of $10^{\circ} \mathrm{C} / \mathrm{min}$ for $4 \mathrm{~h}$. The support was further impregnated with aqueous solutions containing the required amounts of $\left(\mathrm{NH}_{4}\right)_{6} \mathrm{Mo}_{7} \mathrm{O}_{24}, \mathrm{Co}\left(\mathrm{CH}_{3} \mathrm{COO}\right)_{2}$, and $\mathrm{Ni}\left(\mathrm{NO}_{3}\right)_{2}$, followed by drying at $120^{\circ} \mathrm{C}$ for $2 \mathrm{~h}$ and stabilizing in an argon flow of $50 \mathrm{~mL} / \mathrm{min}$ at $450^{\circ} \mathrm{C}$, at a heating rate of $10^{\circ} \mathrm{C} / \mathrm{min}$ for $12 \mathrm{~h}$.

To obtain samples in sulfided form for characterization techniques, the catalysts were first sulfided for $6 \mathrm{~h}$ at $450^{\circ} \mathrm{C}$ and $500 \mathrm{psi}$, at a heating rate of $2^{\circ} \mathrm{C} / \mathrm{min}$ using a gaseous mixture containing 10 mole $\% \mathrm{H}_{2} \mathrm{~S}$ in $\mathrm{H}_{2}$ at a flow rate of $50 \mathrm{~mL} / \mathrm{min}$. The catalysts were then cooled to room temperature in a flow of $\mathrm{He}$, and the sample was transferred to sample holders under protection of $\mathrm{He}$.

2.2. Catalyst Characterization. The surface area, pore volume, and average pore diameter of sulfide samples were measured by $\mathrm{N}_{2}$-physisorption at $77 \mathrm{~K}$ using a Micromeritics ASAP 2000. Approximately $0.2 \mathrm{~g}$ of sample was used for each analysis. The moisture and other adsorbed gases present in the sample were removed before analysis by degassing the sample at $200^{\circ} \mathrm{C}$ for $2 \mathrm{~h}$ under $66.7 * 10^{-6} \mathrm{MPa}$ $(500 \mathrm{mmHg})$. The sample was then evacuated at $2.67 *$ $10^{-6} \mathrm{MPa}(0.02 \mathrm{mmHg})$ before $\mathrm{N}_{2}$ adsorption.

The contents of Mo, Co, and $\mathrm{Ni}$ of the sulfide catalysts were determined using a Perkin-Elmer ELAN 5000 inductively coupled plasma mass spectroscopy (ICP-MS) instrument.

Powder X-ray diffraction (XRD) analysis patterns of sulfide forms of samples were recorded on a Rigaku X-ray diffraction instrument with nickel filtered $\mathrm{Cu} \mathrm{K} \alpha$ radiation $(\lambda=0.1541 \mathrm{~nm})$. Each sample was scanned at a rate of $0.05^{\circ} / \mathrm{s}$, with $2 \theta$ varying from 10 to $80^{\circ}$.

The morphology of the sulfided samples was characterized by transmission electron microscopy (TEM) investigations, using a Philips CM20 $(100 \mathrm{kV})$ transmission electron microscope equipped with a NARON energy-dispersive spectrometer with a germanium detector.

2.3. Catalytic Studies. The catalytic conversion of synthesis gas to higher alcohols was performed using the feed gas mixture CO (40 mole \%), $\mathrm{H}_{2}$ (50 mole\%), and Ar (10 mole\%) in a single-pass tubular downflow fixed-bed reactor under the reaction conditions of $330^{\circ} \mathrm{C}, 9.1 \mathrm{MPa}(1320 \mathrm{psig})$, and $3.8 \mathrm{~m}^{3}$ (STP) $/ \mathrm{hr} /(\mathrm{kg}$ of catalyst) over a period of $48 \mathrm{~h}$, including an induction period of $24 \mathrm{~h}$. The detailed description about the high-pressure reaction set-up used in this study was discussed in our previous papers $[8,13,18,19,23-26]$. Prior to the reaction, the catalyst was reduced and sulfided for $6 \mathrm{~h}$ at $450^{\circ} \mathrm{C}$ at a heating rate of $2^{\circ} \mathrm{C} / \mathrm{min}$ using a gas mixture containing $10 \mathrm{~mol} \% \mathrm{H}_{2} \mathrm{~S}$ in $\mathrm{H}_{2}$ and a flow rate of $50 \mathrm{~mL} / \mathrm{min}$. The product gas was cooled to $0^{\circ} \mathrm{C}$ and separated into gas and liquid phases at the reaction pressure. The liquid 
TABLE 1: Elemental compositions of sulfided catalysts.

\begin{tabular}{|c|c|c|c|c|c|c|c|}
\hline \multirow{2}{*}{ Catalyst } & \multicolumn{4}{|c|}{ Targeted composition (wt\%) } & \multicolumn{3}{|c|}{ Measured composition (wt\%) } \\
\hline & K & Mo & Co & $\mathrm{Ni}$ & Mo & Co & $\mathrm{Ni}$ \\
\hline Acid Treated MWCNT & - & - & - & - & - & - & - \\
\hline Co-Mo-K/MWCNT & 9 & 15 & 4.5 & - & 14.3 & 4.3 & - \\
\hline 1.5 wt\% Ni-Co-Mo-K/MWCNTs & 9 & 15 & 4.5 & 1.5 & 13.9 & 4.1 & 1.2 \\
\hline $3.0 \mathrm{wt} \% \mathrm{Ni}-\mathrm{Co}-\mathrm{Mo}-\mathrm{K} / \mathrm{MWCNTs}$ & 9 & 15 & 4.5 & 3.0 & 13.7 & 4.0 & 2.5 \\
\hline 4.5 wt $\%$ Ni-Co-Mo-K/MWCNTs & 9 & 15 & 4.5 & 4.5 & 14.1 & 3.8 & 3.9 \\
\hline $6 \mathrm{wt} \% \mathrm{Ni}-\mathrm{Co}-\mathrm{Mo}-\mathrm{K} / \mathrm{MWCNTs}$ & 9 & 15 & 4.5 & 6.0 & 13.6 & 4.3 & 5.7 \\
\hline
\end{tabular}

TABLE 2: Textural characteristics of catalysts in sulfide form.

\begin{tabular}{lccc}
\hline Catalyst & BET surface area $\left(\mathrm{m}^{2} / \mathrm{g}\right)$ & Total pore volume $(\mathrm{cc} / \mathrm{g})$ & Average pore diameter $(\mathrm{nm})$ \\
\hline Acid Treated MWCNT & 220 & 0.66 & 10.9 \\
Co-Mo-K/MWCNT & 89 & 0.36 & 15.7 \\
$1.5 \mathrm{wt} \%$ Ni-Co-Mo-K/MWCNTs & 80 & 0.30 & 16.9 \\
$3.0 \mathrm{wt} \%$ Ni-Co-Mo-K/MWCNTs & 72 & 0.25 & 17.4 \\
$4.5 \mathrm{wt} \%$ Ni-Co-Mo-K/MWCNTs & 65 & 0.19 & 18.1 \\
$6 \mathrm{wt} \%$ Ni-Co-Mo-K/MWCNTs & 57 & 0.12 & 18.8 \\
\hline
\end{tabular}

products were collected at the end of the reaction and analyzed with a Varian 3400 gas chromatograph equipped with a capillary column and a flame ionization detector (FID). The gaseous products were analyzed online on a Shimadzu gas chromatograph through a sampling valve for every $1 \mathrm{~h}$. The experiments were repeated at least twice to check reproducibility and to confirm that the results obtained were within the experimental error of $\pm 2.5 \%$.

Mass balance calculations similar to those proposed by Bahome et al. [27] were used to calculate the \% CO conversion, $\% \mathrm{CO}_{2}$ produced, product space time yield (STY), and alcohol selectivity (wt.\%) and are given as follows:

$\%$ CO Conversion

$$
=\frac{\operatorname{Moles}\left(\mathrm{CO}_{\mathrm{in}}-\mathrm{CO}_{\text {out }}\right) \times \text { gas contraction }}{\operatorname{Moles}\left(\mathrm{CO}_{\mathrm{in}}\right)} \times 100 \text {, }
$$

where the gas contraction was determined from the $\mathrm{Ar}_{\mathrm{in}} / \mathrm{Ar}_{\text {out }}$ calibration. Consider

$$
\begin{aligned}
\% \mathrm{CO}_{2} \text { produced } & =\frac{\text { Moles of } \mathrm{CO}_{2} \text { produced }}{\text { Moles of } \mathrm{CO}_{2} \text { converted }} \times 100, \\
\text { Product STY } & =\frac{\text { Wt. of the product produced }}{\text { Wt. of cat. } / \mathrm{hr}},
\end{aligned}
$$

Alcohol Selectivity (wt.\%)

$$
=\frac{\text { Wt. of the alcohol produced }}{\text { Total wt. of the producted }} \times 100 \text {. }
$$

\section{Results and Discussion}

3.1. Catalyst Characterization. The Ni, Co, and Mo contents of the stabilized catalysts are measured by ICP-MS after sulfidation and are reported in Table 1 along with the targeted compositions. The measured contents of the prepared catalysts are slightly lower compared to targeted values, which may be due to the hygroscopic nature of precursors.

Table 2 shows the results for surface area, total pore volume, and average pore diameter of the stabilized catalysts in sulfide form. The BET surface area of the MWCNTs increased from 178 to $220 \mathrm{~m}^{2} / \mathrm{g}$ after acid treatment. Acid treatment opens the nanotube caps and removes impurities from the MWCNTs. The MWCNT-supported bimetallic (4.5 wt $\%$ Co and $15 \mathrm{wt} \% \mathrm{Mo}$ ) catalyst promoted with $9 \mathrm{wt} \% \mathrm{~K}$ showed a BET surface area of $89 \mathrm{~m}^{2} / \mathrm{g}$ and a total pore volume of $0.36 \mathrm{~cm}^{3} / \mathrm{g}$, increasing the amount of Ni from 1.5 to $6 \mathrm{wt} \%$ and decreasing the BET surface area of the MWCNT-supported alkali-promoted trimetallic catalysts from 80 to $57 \mathrm{~m}^{2} / \mathrm{g}$ and the total pore volume from 0.30 to $0.12 \mathrm{~cm}^{3} / \mathrm{g}$.

The typical XRD patterns of the second screening catalysts are shown in Figure 1. Apart from the peaks for the support, MWCNTs $\left(2 \theta=27\right.$ and $\left.43.5^{\circ}\right)$, there are no peaks with significant intensity indicating that the metal particles are finely dispersed and smaller than the detection limit of the XRD instrument.

TEM images of the catalysts were recorded and the representative image of a $3.0 \mathrm{wt} \% \mathrm{Ni}$-promoted Mo-K/MWCNT catalyst was selected from several micrographs and is shown in Figure 2. The carbon nanotube size and particle size are measured using imaging particle analyzer. The carbon nanotubes are multi-walled, with inner diameters in the range of $8-15 \mathrm{~nm}$ and wall thickness in the range of 5 to $10 \mathrm{~nm}$. Most of the nanotube caps are found to be open. No amorphous carbon or other impurities are observed in and around the tubes. The particle sizes of the metal species that are inside $(\sim 60 \%)$ and outside $(\sim 40 \%)$ of the tubes are in the range of $3-5 \mathrm{~nm}$. This revealed that the catalyst particles are well dispersed both inside the carbon nanotubes and on the outside of the tube walls. 


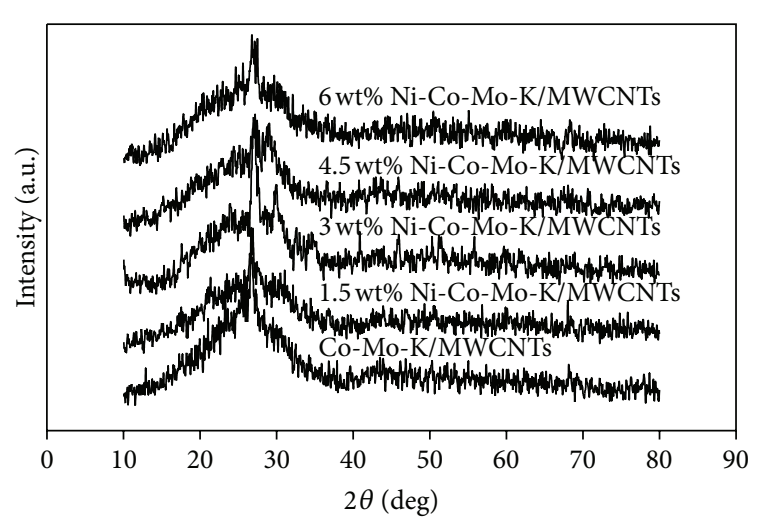

FIGURE 1: XRD patterns of catalysts in sulfide form.

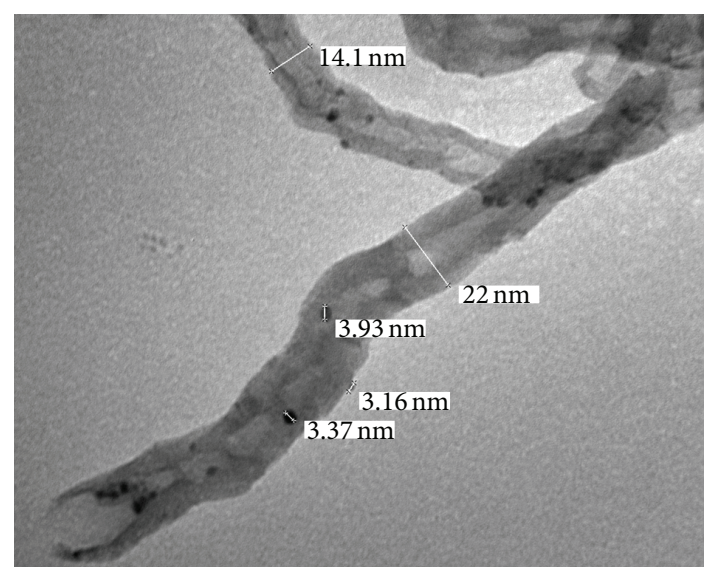

FIGURE 2: TEM image of $3 \mathrm{wt} \% \mathrm{Ni}-\mathrm{Co}-\mathrm{Mo}-\mathrm{K} / \mathrm{MWCNT}$.

3.2. Catalytic Studies. The catalyst activity studies towards higher alcohol synthesis reaction were carried out under similar conditions at $330^{\circ} \mathrm{C}, 9.1(1320 \mathrm{psig})$, and $3.8 \mathrm{~m}^{3}$ (STP) $/ \mathrm{hr} /$ (kg of catalyst) over a period of $48 \mathrm{~h}$, including an induction period of $24 \mathrm{~h}$. Figure 3 gives the results of the percentage CO conversion as time-on-stream during $48 \mathrm{~h}$ of higher alcohols synthesis over MWCNT-supported alkalimodified Ni-promoted Co-Mo catalysts. CO conversion sharply reduced in the first $18 \mathrm{~h}$ and then levelled off, indicating that the catalyst was quite stable after $18 \mathrm{~h}$ of time-on-stream during the $48 \mathrm{~h}$ alcohol synthesis. A $43 \%$ $\mathrm{CO}$ conversion is observed on the alkali-modified bimetallic Co-Mo catalyst supported on MWCNTs. \% CO conversion increased from $47 \%$ to $56 \%$ with increased $\mathrm{Ni}$ content from 1.5 to $6 \mathrm{wt} \%$ over the alkali-modified Ni-Co-Mo trimetallic catalysts supported on MWCNTs. The catalytic activity and product selectivity data were calculated after an induction period of $24 \mathrm{~h}$.

The analysis of the liquid products indicates that linear alcohols are formed and no branched alcohols were observed in the GC trace corresponding to the higher alcohols. This analysis confirmed that higher alcohols synthesis from $\mathrm{CO}$ hydrogenation over alkali-modified trimetallic Ni-Co-Mo

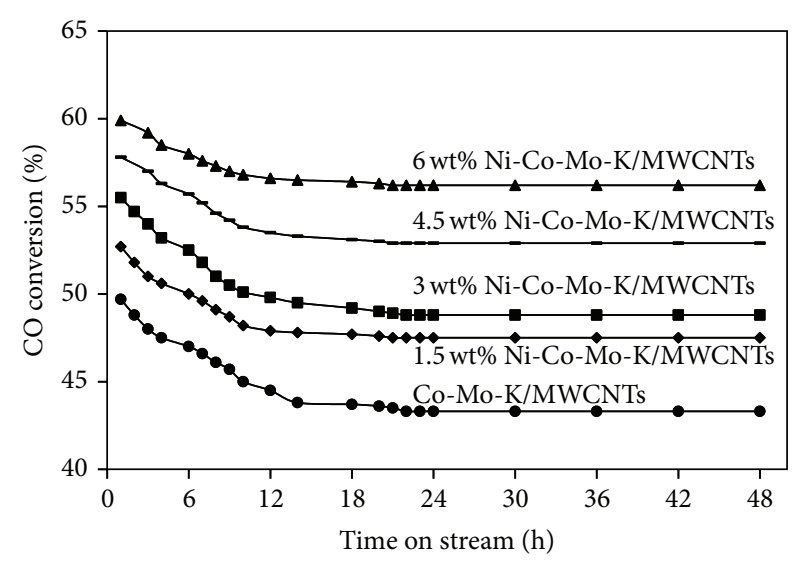

Figure 3: \% CO conversion with time-on-stream (wt. of the catalyst $=2 \mathrm{~g}, P=9.0 \mathrm{MPa}(1300 \mathrm{psig}), T=330^{\circ} \mathrm{C}, \mathrm{GHSV}=3.8 \mathrm{~m}^{3}$ $(\mathrm{STP}) / \mathrm{h} / \mathrm{kg}$ of catalyst, $\mathrm{H}_{2} / \mathrm{CO}$ molar ratio $\left.=1.25\right)$.

catalysts likely follow a $\mathrm{CO}$ insertion mechanism as suggested by Santiesteban [31]. Methanol, ethanol, n-propanol, and nbutanol are the major products, together with other higher alcohols. The analysis of exit gas indicates that methane is the major component apart from $\mathrm{CO}_{2}$ and unconverted gases, such as, $\mathrm{CO}, \mathrm{H}_{2}$, and Ar.

Table 3 shows the activity and selectivity results obtained from $\mathrm{CO}$ hydrogenation over the sulfided alkali-modified $\mathrm{Ni}$ Co-Mo catalysts. The term higher alcohols represents the ethanol and alcohols with a carbon number greater than $2\left(\mathrm{C}_{2+}\right.$ alcohols). The total alcohols and total hydrocarbons space time yields (STYs) of 0.239 and $0.352 \mathrm{gm} /(\mathrm{gm}$ of cat./h), respectively, are observed over the nickel-free MWCNT-supported catalyst. With the addition of $1.5 \mathrm{wt} \%$ $\mathrm{Ni}$ on the MWCNT-supported $4.5 \mathrm{wt} \% \mathrm{Co}, 15 \mathrm{wt} \% \mathrm{Mo}$, and $9 \mathrm{wt} \% \mathrm{~K}$ catalyst, the total alcohols and total hydrocarbon STY increased to 0.262 and $0.361 \mathrm{gm} /(\mathrm{gm}$ of cat. $) / \mathrm{h}$, respectively. The methanol, ethanol, and higher alcohols selectivity increased from $5.3 \%, 16.8 \%$, and $26.6 \%$ over the alkali-modified bimetallic Co-Mo/MWCNT catalyst to 7.1\%, $18.9 \%$, and $29.4 \%$ on the MWCNT-supported alkali-modified trimetallic catalyst promoted with $1.5 \mathrm{wt} \% \mathrm{Ni}$. By increasing the Ni loading from 1.5 to $3 \mathrm{wt} \%$ on the MWCNT-supported trimetallic catalyst, the total alcohols STY increased from 0.262 to $0.284 \mathrm{gm} /(\mathrm{gm}$ of cat.) $/ \mathrm{h}$ and total hydrocarbons STY increased from 0.361 to $0.375 \mathrm{gm} /(\mathrm{gm}$ of cat.)/h. These results confirmed that nickel promoter not only improved the formation of alcohols but also benefited the formation of hydrocarbons.

The total alcohols STYs are comparatively low over 4.5 and $6 \mathrm{wt} \% \mathrm{Ni}$-promoted alkali-modified trimetallic catalysts supported on MWCNTs, than that of the catalyst with $3 \mathrm{wt} \%$ $\mathrm{Ni}$ content. Chung and Pien [16] observed the formation of $\mathrm{NiO}$ species at higher $\mathrm{Ni}$ content in $\mathrm{H}_{2}$-TPR studies. Hydrocarbon STYs of 0.388 and $0.403 \mathrm{gm} /(\mathrm{gm}$ of cat.) $/ \mathrm{h}$ are observed over the alkali-modified trimetallic catalysts supported on MWCNTs promoted with 4.5 and $6 \mathrm{wt} \% \mathrm{Ni}$, respectively, which may be due to increased formation of 
TABLE 3: Catalytic performance of sulfided MWCNT-supported catalysts (wt. of the catalyst $=2 \mathrm{gm}, P=9.0 \mathrm{MPa}(1300 \mathrm{psig}), \mathrm{T}=330^{\circ} \mathrm{C}$, $\mathrm{GHSV}=3.8 \mathrm{~m}^{3}(\mathrm{STP}) / \mathrm{hr} / \mathrm{kg}$ of catalyst, $\mathrm{H}_{2} / \mathrm{CO}$ molar ratio $\left.=1.25\right)$.

\begin{tabular}{|c|c|c|c|c|c|c|c|c|}
\hline \multirow[t]{2}{*}{ Catalyst } & \multirow[b]{2}{*}{$\begin{array}{c}\text { CO conversion } \\
(\%)\end{array}$} & \multicolumn{2}{|c|}{$\begin{array}{l}\text { Product STY } \\
(\mathrm{gm} /(\text { gm of cat. }) / \mathrm{h})\end{array}$} & \multirow[b]{2}{*}{$\begin{array}{l}\mathrm{CO}_{2} \text { produced } \\
\quad(\mathrm{mol} . \%)\end{array}$} & \multicolumn{4}{|c|}{ Alcohol selectivity (wt \%) } \\
\hline & & $\begin{array}{c}\text { Total } \\
\text { alcohols }\end{array}$ & $\begin{array}{c}\text { Total } \\
\text { Hydrocarbons }\end{array}$ & & Methanol & Ethanol & $\begin{array}{l}\text { Higher } \\
\text { alcohols }\end{array}$ & $\begin{array}{l}\text { Total } \\
\text { alcohols }\end{array}$ \\
\hline Co-Mo-K/MWCNTs & 43.3 & 0.239 & 0.352 & 36.6 & 5.3 & 16.8 & 26.6 & 31.9 \\
\hline $\begin{array}{l}1.5 \mathrm{wt} \% \\
\mathrm{Ni}-\mathrm{Co}-\mathrm{Mo}-\mathrm{K} / \mathrm{MWCNTs}\end{array}$ & 47.5 & 0.262 & 0.361 & 37.1 & 7.1 & 18.9 & 29.4 & 36.5 \\
\hline $\begin{array}{l}3 \mathrm{wt} \% \\
\text { Ni-Co-Mo-K/MWCNTs }\end{array}$ & 48.8 & 0.284 & 0.375 & 38.2 & 7.9 & 20.2 & 32.8 & 40.7 \\
\hline $\begin{array}{l}4.5 \mathrm{wt} \% \\
\mathrm{Ni}-\mathrm{Co}-\mathrm{Mo}-\mathrm{K} / \mathrm{MWCNTs}\end{array}$ & 52.9 & 0.275 & 0.388 & 40.1 & 7.5 & 19.5 & 32.1 & 39.6 \\
\hline $\begin{array}{l}6 \mathrm{wt} \% \\
\mathrm{Ni}-\mathrm{Co}-\mathrm{Mo}-\mathrm{K} / \mathrm{MWCNTs}\end{array}$ & 56.2 & 0.269 & 0.403 & 41.5 & 6.8 & 18.1 & 29.9 & 36.7 \\
\hline
\end{tabular}

TABLE 4: Comparison of the activities of alkali-modified molybdenum-based catalysts promoted with transition metals.

\begin{tabular}{|c|c|c|c|c|c|}
\hline Reference & Li et al., 2001 [28] & Li et al., 2001 [29] & Qi et al., 2003 [30] & Surisetty et al., 2010 [13] & Present work \\
\hline Catalyst & Mo-K/AC & Co-Mo-K/AC & Ni-Mo-K & Co-Mo-K/MWCNT & Ni-Co-Mo-K /MWCNT \\
\hline Temperature $\left({ }^{\circ} \mathrm{C}\right)$ & 330 & 330 & 315 & 330 & 330 \\
\hline Pressure (MPa) & 5.0 & 5.0 & 9.5 & 8.3 & 9.0 \\
\hline $\mathrm{H}_{2} / \mathrm{CO}$ molar ratio & 2.0 & 2.0 & 2.0 & 1.0 & 1.25 \\
\hline $\begin{array}{l}\text { GHSV }\left(\mathrm{L} / \mathrm{kg}_{\text {cat. }} / \mathrm{h}\right) \\
*\left(\mathrm{~h}^{-1}\right)\end{array}$ & 7200 & $* 4800$ & 6000 & 3600 & 3800 \\
\hline CO conversion $(\%)$ & 13 & $14\left(\mathrm{CO}_{2}\right.$-free $)$ & 23 & 45 & 49 \\
\hline $\begin{array}{l}\text { STY of total alcohols } \\
{ }^{\dagger}\left(\mathrm{g} / \mathrm{g}_{\text {cat }} / \mathrm{h}\right) \\
{ }^{\dagger}\left(\mathrm{g} / \mathrm{mL}_{\text {cat. }} / \mathrm{h}\right)\left(\mathrm{mL} / \mathrm{g}_{\text {cat. }} / \mathrm{h}\right)\end{array}$ & ${ }^{\dagger} 23.1$ & ${ }^{\dagger \dagger} 0.199$ & 0.220 & 0.236 & 0.284 \\
\hline $\begin{array}{l}\text { STY of higher alcohols }\left(\mathrm{g} / \mathrm{g}_{\text {cat. }} / \mathrm{h}\right) \\
\&\left(\mathrm{CO} \mathrm{mol} / \mathrm{kg}_{\text {cat }} / \mathrm{h}\right) \\
\& \&\left(\mathrm{~mL} / \mathrm{g}_{\text {cat. }} / \mathrm{h}\right)\end{array}$ & ${ }^{8} 12.1$ & ${ }^{\& \&} 0.114$ & - & 0.171 & 0.228 \\
\hline $\begin{array}{l}\text { STY of hydrocarbon }(\mathrm{g} / \mathrm{gcat} . / \mathrm{h}) \\
¥(\% \text { of CO })\end{array}$ & $¥ 38$ & - & - & 0.395 & 0.375 \\
\hline $\begin{array}{l}\text { Total alcohols selectivity } \\
(\mathrm{wt} \%)\end{array}$ & - & $47\left(\mathrm{CO}_{2}\right.$-free $)$ & $60\left(\mathrm{CO}_{2}\right.$-free $)$ & 32 & 43 \\
\hline
\end{tabular}

$\mathrm{NiO}$ species. These results confirmed that the methanation activity of the catalyst is increased at higher $\mathrm{Ni}$ (4.5 and $6 \mathrm{wt} . \%)$ contents. The selectivity of methanol, ethanol, and higher alcohols is found to be low on the 4.5 and $6 \mathrm{wt} \% \mathrm{Ni}$ promoted catalysts compared to that of catalysts with less $\mathrm{Ni}$ content, which can be explained due to the formation of hydrocarbons. The water-gas-shift reaction rate increased from $37 \%$ to $42 \%$ with increased Ni content from 0 to $6 \mathrm{wt} \%$ over the alkali-modified trimetallic catalysts supported on MWCNTs.

Figure 4 represents the molar percentage distribution of alcohols on 3 wt $\%$ Ni-promoted Co-Mo-K/MWCNTs catalysts. Ethanol is the major product (41\%) together with methanol (22\%), propanol (15\%), and butanol (12\%). A little amount of higher alcohols $\left(\mathrm{C}_{n}>4\right)$ up to octanol is also detected over these Ni-promoted CoMo-K/MWCNTs catalysts. These results confirmed that $\mathrm{Ni}$ promotes the activity and selectivity toward higher alcohols (particularly ethyl alcohol).

Table 4 compares the activities of sulfided 3 wt. $\% \mathrm{Ni}$, 4.5 wt.\% Co, 15 wt.\% Mo, and 9 wt.\% K supported on MWCNTs with those of other catalysts discussed in the literature. It can be observed from this table that the addition of transition metals such as $\mathrm{Ni}$ and Co to alkali-modified molybdenumbased catalysts improved CO hydrogenation which enhanced space time yield of methanol, higher alcohols, and hydrocarbons [13, 28-30, 32]. The catalyst with the highest activity from each work was selected for comparison purposes. From Table 4 it can be observed that the alcohol STY of $0.285 \mathrm{gm} /(\mathrm{gm}$ of cat./h) over sulfided alkali-modified NiCo-Mo catalysts supported on MWCNT at $1300 \mathrm{psig}, 330^{\circ} \mathrm{C}$, $3.8 \mathrm{~m}^{3}$ (STP)/hr/kg of catalyst and $\mathrm{H}_{2} / \mathrm{CO}$ molar ratio of 1.25 is better than that the catalyst performance reported in the literature. 


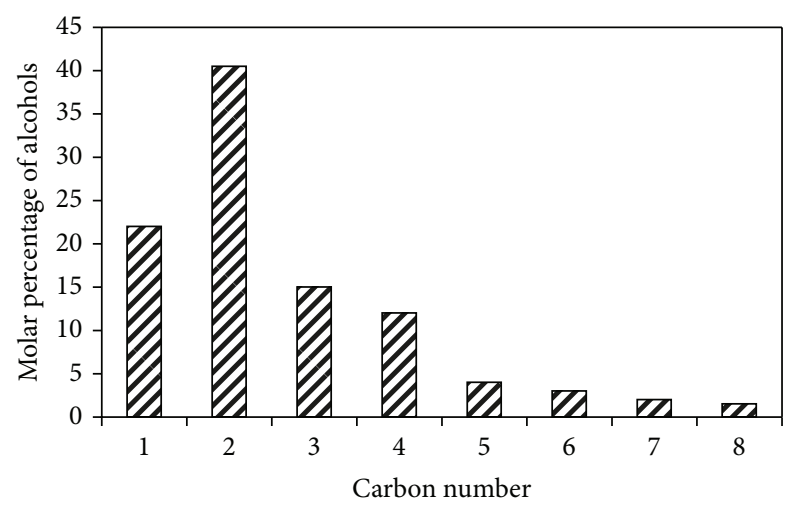

Figure 4: Molar percentage of alcohols over the catalyst $3 \mathrm{wt} \% \mathrm{Ni}$ Mo-K/MWCNTs (wt. of the catalyst $=2 \mathrm{~g}, P=9.0 \mathrm{MPa}$ (1300 psig), $T=330^{\circ} \mathrm{C}, \mathrm{GHSV}=3.8 \mathrm{~m}^{3}(\mathrm{STP}) / \mathrm{h} / \mathrm{kg}$ of catalyst, $\mathrm{H}_{2} / \mathrm{CO}$ molar ratio $=1.25$ ).

\section{Conclusions}

The incorporation of Ni to the alkali-promoted bimetallic CoMo catalyst resulted in substantial changes in both structure properties and catalytic performance. Metal species were uniformly distributed both inside the tubes and on the outside of the tubes, with particle sizes in the range of 1 to $2 \mathrm{~nm}$. The MWCNT-supported alkali-promoted trimetallic catalyst with $3 \mathrm{wt} \%$ Ni showed the highest total alcohols yield of $0.284 \mathrm{gm} /(\mathrm{gm}$ of cat./h), ethanol selectivity of $20.2 \%$, and higher alcohols selectivity of $32.8 \%$ at $330^{\circ} \mathrm{C}$ and $8.96 \mathrm{MPa}$ using gas hourly space velocity (GHSV) of $3.8 \mathrm{~m}^{3}$ (STP) $/ \mathrm{kg}$ of catalyst/h and $\mathrm{H}_{2}$ to $\mathrm{CO}$ molar ratio of 1.25 . Ni-promotion to K-modified Co-Mo catalysts supported on MWCNTs improved the activity and selectivity toward higher alcohols (particularly ethyl alcohol).

\section{References}

[1] V. Mahdavia, M. H. Peyrovia, M. Islamib, and J. Yegane Mehrb, "Synthesis of higher alcohols from syngas over $\mathrm{Cu}-$ $\mathrm{Co}_{2} \mathrm{O}_{3} / \mathrm{ZnO}, \mathrm{Al}_{2} \mathrm{O}_{3}$ catalyst," Applied Catalysis A, vol. 281, no. 1-2, pp. 259-265, 2005.

[2] V. R. Surisetty, J. Kozinski, and A. K. Dalai, "Alcohols as alternative fuels: an overview," Applied Catalysis A, vol. 404, no. 1-2, pp. 1-11, 2011.

[3] P. Forzatti, E. Tronconi, and I. Pasquon, "Higher alcohol synthesis," Catalysis Reviews, vol. 33, no. 1-2, pp. 109-168, 1991.

[4] J. M. Campos-Martín, J. L. G. Fierro, A. Guerrero-Ruiz, R. G. Herman, and K. Klier, "Promoter effect of cesium on C$\mathrm{C}$ bond formation during alcohol synthesis from $\mathrm{CO} / \mathrm{H}_{2}$ over $\mathrm{Cu} / \mathrm{ZnO} / \mathrm{Cr}_{2} \mathrm{O}_{3}$ catalysts," Journal of Catalysis, vol. 163, no. 2, pp. 418-428, 1996.

[5] R. Xu, C. Yang, W. Wei, W. H. Li, Y. H. Sun, and T. D. Hu, "Fe-modified $\mathrm{CuMnZ \textrm {rO } _ { 2 }}$ catalysts for higher alcohols synthesis from syngas," Journal of Molecular Catalysis A, vol. 221, no. 1-2, pp. 51-58, 2004.

[6] X. Xiaoding, E. B. M. Doesburg, and J. J. F. Scholten, "Synthesis of higher alcohols from syngas-recently patented catalysts and tentative ideas on the mechanism," Catalysis Today, vol. 2, no. 1, pp. 125-170, 1987.
[7] H. C. Woo and K. Y. Park, "Mixed alcohol synthesis from carbon monoxide and dihydrogen over potassium-promoted molybdenum carbide catalysts," Applied Catalysis, vol. 75, no. 1, pp. 267-280, 1991.

[8] V. R. Surisetty, A. Tavasoli, and A. K. Dalai, "Synthesis of higher alcohols from syngas over alkali promoted $\mathrm{MoS}_{2}$ catalysts supported on multi-walled carbon nanotubes," Applied Catalysis A, vol. 365, no. 2, pp. 243-251, 2009.

[9] C. B. Murchison, M. M. Conway, R. R. Stevens, and G. J. Qurarderer, "Process for producing olefins from carbon monoxide and hydrogen," in in Proceedings of the 9th International Congress on Catalysis, vol. 2, p. 561, 1988.

[10] J. Iranmahboob, D. O. Hill, and H. Toghiani, " $\mathrm{K}_{2} \mathrm{CO}_{3} / \mathrm{Co}-$ $\mathrm{MoS}_{2}$ /clay catalyst for synthesis of alcohol: influence of potassium and cobalt," Applied Catalysis A, vol. 231, no. 1-2, pp. 99108, 2002.

[11] A. Fujumoto and T. Oba, "Synthesis of $\mathrm{C}_{1}-\mathrm{C}_{7}$ alcohols from synthesis gas with supported cobalt catalysts," Applied Catalysis, vol. 13, pp. 289-319, 1985.

[12] V. R. Surisetty, Y. Hu, A. K. Dalai, and J. Kozinski, "Structural characterization and catalytic performance of alkali $(\mathrm{K})$ and metal (Co and Rh)-promoted $\mathrm{MoS}_{2}$ catalysts for higher alcohols synthesis," Applied Catalysis A, vol. 392, no. 1-2, pp. 166-172, 2011.

[13] V. R. Surisetty, A. K. Dalai, and J. Kozinski, "Synthesis of higher alcohols from synthesis gas over Co-promoted alkali-modified $\mathrm{MoS}_{2}$ catalysts supported on MWCNTs," Applied Catalysis A, vol. 385, no. 1-2, pp. 153-162, 2010.

[14] D. B. Li, C. Yang, H. J. Qi, W. H. Li, Y. H. Sun, and B. Zhong, "Higher alcohol synthesis over a La promoted Ni/K $\mathrm{K}_{2} \mathrm{CO}_{3} / \mathrm{MoS}_{2}$ catalyst," Catalysis Communications, vol. 5, no. 10, pp. 605-609, 2004.

[15] S. A. Hedrick, S. S. C. Chuang, A. Pant, and A. G. Dastidar, "Activity and selectivity of Group VIII, alkali-promoted Mn$\mathrm{Ni}$, and Mo-based catalysts for $\mathrm{C}_{2+}$ oxygenate synthesis from the $\mathrm{CO}$ hydrogenation and $\mathrm{CO} / \mathrm{H}_{2} / \mathrm{C}_{2} \mathrm{H}_{4}$ reactions," Catalysis Today, vol. 55, no. 3, pp. 247-257, 2000.

[16] S. S. C. Chuang and S. I. Pien, "Infrared studies of reaction of ethylene with syngas on $\mathrm{Ni} / \mathrm{SiO}_{2}$," Catalysis Letters, vol. 3, no. 4, pp. 323-329, 1989.

[17] M. A. Haider, M. R. Gogate, and R. J. Davis, "Fe-promotion of supported $\mathrm{Rh}$ catalysts for direct conversion of syngas to ethanol," Journal of Catalysis, vol. 261, no. 1, pp. 9-16, 2009.

[18] V. R. Surisetty, A. K. Dalai, and J. Kozinski, "Effect of Rh promoter on MWCNT-supported alkali-modified $\mathrm{MoS}_{2}$ catalysts for higher alcohols synthesis from CO hydrogenation," Applied Catalysis A, vol. 381, no. 1-2, pp. 282-288, 2010.

[19] V. R. Surisetty, A. K. Dalai, and J. Kozinski, "Alkali-promoted trimetallic Co-Rh-Mo sulfide catalysts for higher alcohols synthesis from synthesis gas: comparison of MWCNT and activated carbon supports," Industrial \& Engineering Chemistry Research, vol. 49, pp. 6845-6853, 2010.

[20] P. J. Van Berge, J. Van De Loosdrecht, S. Barradas, and A. M. Van Der Kraan, "Oxidation of cobalt based Fischer-Tropsch catalysts as a deactivation mechanism," Catalysis Today, vol. 58, no. 4, pp. 321-334, 2000.

[21] P. Serp, M. Corrias, and P. Kalck, "Carbon nanotubes and nanofibers in catalysis," Applied Catalysis A, vol. 253, no. 2, pp. 337-358, 2003. 
[22] M. Xiaoming, L. Guodong, and Z. Hongbin, "Co-Mo-K sulfide-based catalyst promoted by multiwalled carbon nanotubes for higher alcohol synthesis from syngas ," Chinese Journal of Catalysis, vol. 27, no. 11, pp. 1019-1027, 2006.

[23] V. R. Surisetty, A. K. Dalai, and J. Kozinski, "Influence of porous characteristics of the carbon support on alkali-modified trimetallic Co-Rh-Mo sulfided catalysts for higher alcohols synthesis from synthesis gas," Applied Catalysis A, vol. 393, pp. 50-58, 2011.

[24] V. R. Surisetty, A. K. Dalai, and J. Kozinski, "Deactivation studies of alkali-promoted trimetallic Co-Rh-Mo sulfide catalysts for higher alcohols synthesis from synthesis gas," Energy \& Fuels, vol. 25, pp. 580-590, 2011.

[25] V. R. Surisetty, A. K. Dalai, and J. Kozinski, "Intrinsic reaction kinetics of higher alcohol synthesis from synthesis gas over a sulfided alkali-promoted Co-Rh-Mo trimetallic catalyst supported on multiwalled carbon nanotubes (MWCNTs)," Energy \& Fuels, vol. 24, pp. 4130-44137, 2011.

[26] V. R. Surisetty, A. K. Dalai, and J. Kozinski, "Effect of operating conditions for higher alcohols synthesis from synthesis gas over alkali-modified Co-Rh-Mo trimetallic catalyst supported on multi-walled carbon nanotubes," International Journal of Chemical Reactor Engineering, vol. 9, no. 1, 2011.

[27] M. C. Bahome, L. L. Jewell, D. Hildebrandt, D. Glasser, and N. J. Coville, "Fischer-Tropsch synthesis over iron catalysts supported on carbon nanotubes," Applied Catalysis A, vol. 287, pp. 60-67, 2005.

[28] Z. R. Li, Y. L. Fu, M. Jiang, T. D. Hu, T. Liu, and Y. N. Xie, "Active carbon supported Mo-K catalysts used for alcohol synthesis," Journal of Catalysis, vol. 199, no. 2, pp. 155-161, 2001.

[29] Z. Li, Y. Fu, J. Bao et al., "Effect of cobalt promoter on CoMo-K/C catalysts used for mixed alcohol synthesis," Applied Catalysis A, vol. 220, pp. 21-230, 2001.

[30] H. Qi, D. Li, C. Yang et al., "Nickel and manganese co-modified $\mathrm{K} / \mathrm{MoS}_{2}$ catalyst: high performance for higher alcohols synthesis from CO hydrogenation," Catalysis Communications, vol. 4, no. 7, pp. 339-3342, 2003.

[31] J. G. Santiesteban, Alcohol synthesis from carbon-monoxide and hydrogen over MoS2-based catalyst [Ph.D. thesis], Lehigh University, Bethlehem, Pa, USA, 1989.

[32] Z. R. Li, Y. L. Fu, and M. Jiang, "Structures and performance of Rh-Mo-K/Al2O3 catalysts used for mixed alcohol synthesis from synthesis gas," Applied Catalysis A, vol. 187, no. 2, pp. 187198, 1999. 

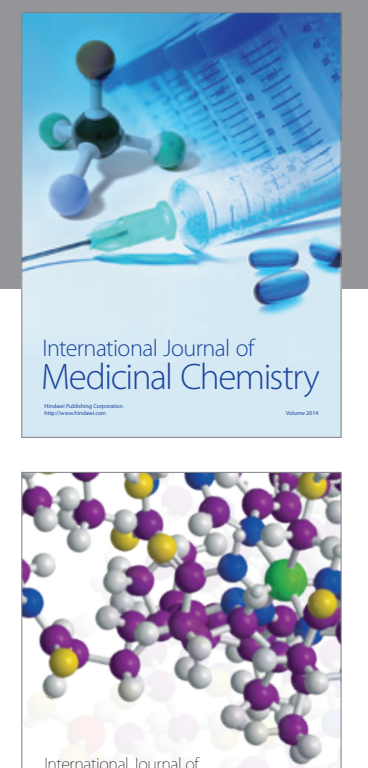

\section{Carbohydrate} Chemistry

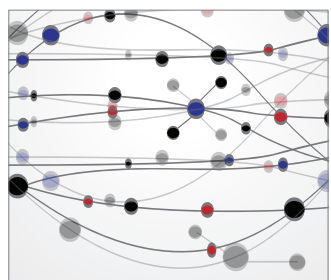

The Scientific World Journal
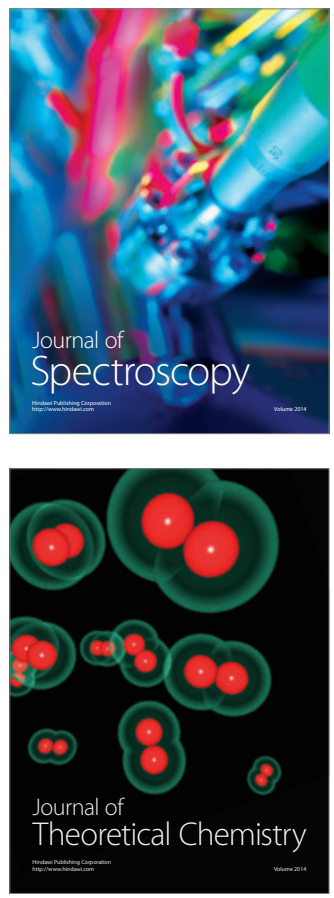
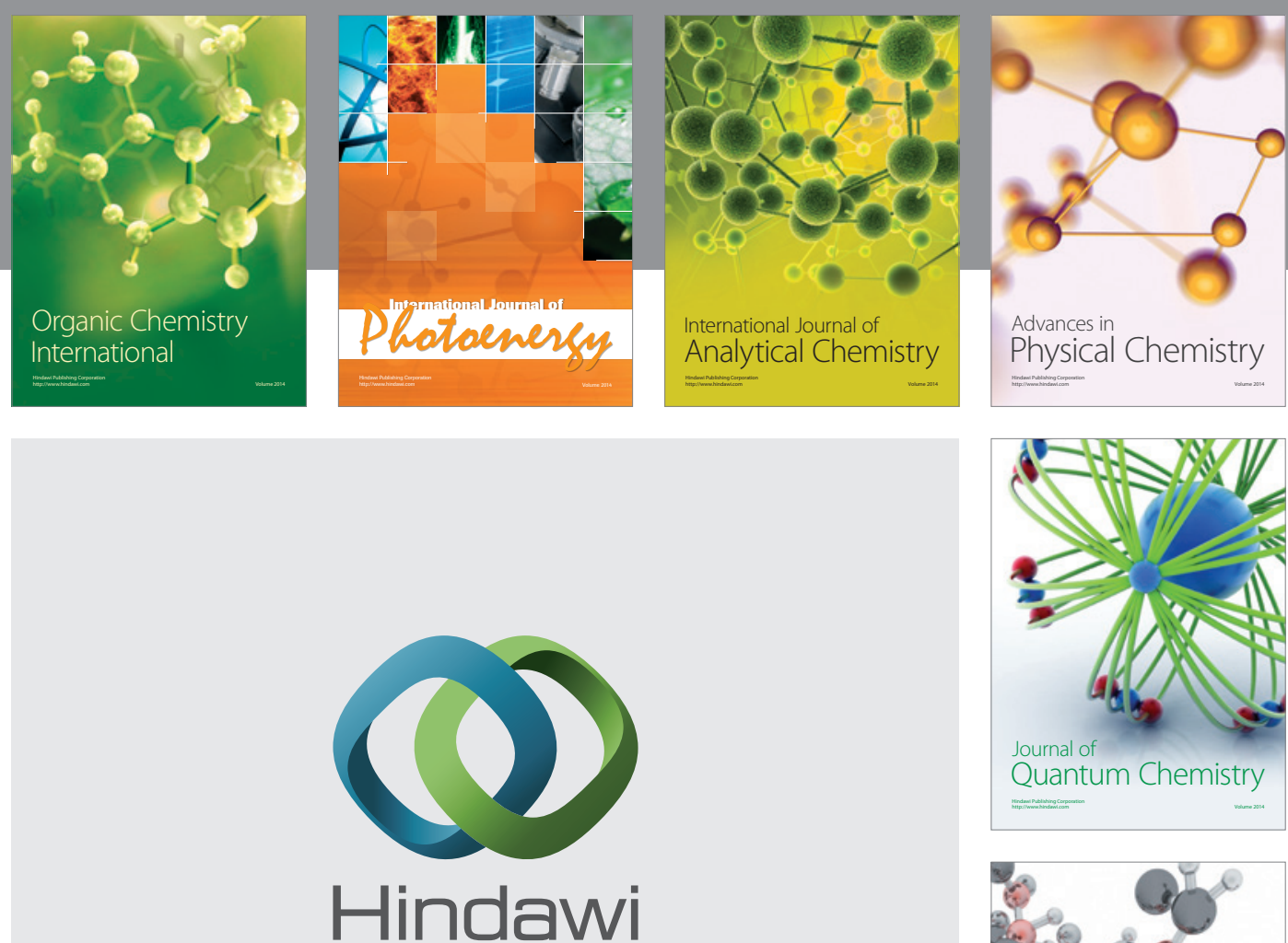

Submit your manuscripts at

http://www.hindawi.com

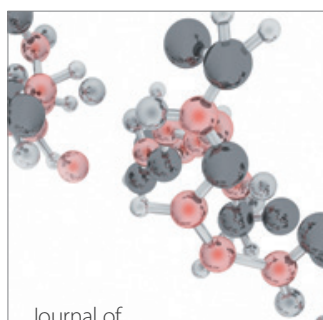

Analytical Methods

in Chemistry

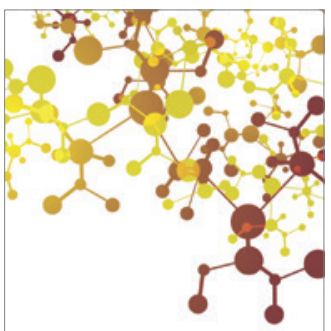

Journal of

Applied Chemistry

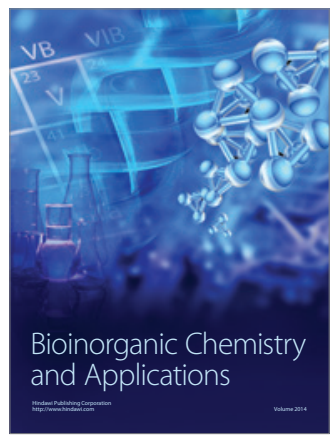

Inorganic Chemistry
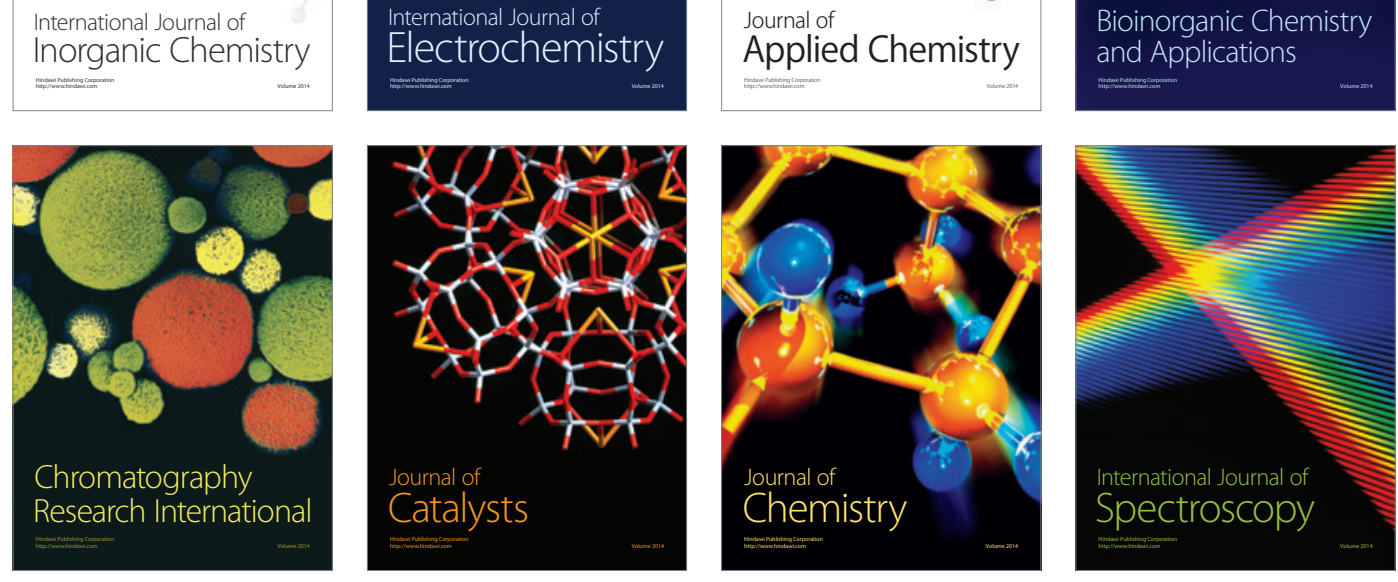